\title{
Strategies in Promoting Eco-policies: The Case of Toyama City, Japan
}

\author{
Hiroshi Ito ${ }^{1}$ \\ ${ }^{1}$ Graduate School of Management, NUCB Business School, Nagoya, Japan \\ Correspondence: Hiroshi Ito, Graduate School of Management, NUCB Business School, 1-3-1 Nishiki, Naka \\ Ward, Nagoya, Aichi 460-0003, Japan. Tel: 81-52-203-8111. E-mail: hito@nucba.ac.jp
}

Received: February 19, 2019

Accepted: March 15, 2019

Online Published: April 30, 2019

doi:10.5539/ass.v15n5p34

URL: https://doi.org/10.5539/ass.v15n5p34

\begin{abstract}
Despite its relatively small population size and limited resources, Toyama City, Japan has been successful in promoting its eco-policies. Because of its substantial work and efforts to address environmental and socio-economic issues, the city was designated as an eco-model city in 2008 and eco-future city in 2011 by the Japanese government as well as a model city of the United Nation's Sustainable Energy for All Initiative in 2014 and the Rockefeller Foundation's 100 Resilient City Initiative in 2014. Through literature reviews and interviews with personnel from the Environmental Policy section at Toyama City Hall, this article describes Toyama City's eco-policies and examines how the city has succeeded in promoting eco-policies at both national and international levels. This study may provide other eco-cities with some insights to promote their eco-policies: Toyama City's case can promote good practices and sound expertise for other cities around the world that have faced similar problems and share lessons learned.
\end{abstract}

Keywords: eco-policy, environmental assessment, promotion strategy, competitive advantage

\section{Introduction: Issues and Strategies of Toyama City's Eco-policies}

Toyama City is located in Hokuriku area, in the central north part of the main island of Japan. The city's population is approximately 420,000 , which is typically considered a middle-size city in Japan. Major industries include high tech, pharmaceuticals, robotics, banking, and hydroelectric power. Toyama City has faced several environmental and socio-economic issues. First, the city has been overly dependent on private transport at 1.79 cars per household (as opposed to 1.61 on average in Japan), the highest level of car ownership in Japan (Karato, 2013). The number of cars owned by Toyama citizens increased from 138,102 in 1990 to 255,542 in 2009, an increase of 1.85 times (Toyama City, 2009). In a reverse trend compared to the growth in ownership of private vehicles, the use of public transportation declined. Between 1989 and 2009, the number of passengers dropped by $28 \%$ for Japan Rail (JR) West lines, $44 \%$ for other private railways, and $43 \%$ for trams. Buses experienced the most remarkable drop at 70\% during the same period (Muro, 2009).

The next issue that Toyama City faces is the city's population is likely to continue diminishing and aging (Future City Initiative, 2017). The population is estimated to decrease by $7.5 \%$ between 2005 and 2025 (Toyama City, 2017a) and the citizens' aging rate (the percentage of the population over 65 in relation to the total population) is currently $30.5 \%$, more than the national average of $26.7 \%$ (Ministry of Internal Affairs and Communication, 2017). Also, the population density rate (40.3 residents/ha) is the lowest among the capital cities of 47 prefectures in Japan (Toyama City, 2009). This demographic landscape leads to declining tax revenues and negatively affects public infrastructure, including transportation, while requiring more resources for the city government to provide public services.

Toyama City has been addressing these issues by what is called the compact city strategy. Toyama's compact city policy is based on the following strategies: 1) to revitalize public transportation, 2) to concentrate city functions in the city center and along the transportation lines, and 3) to promote energy efficiency and alternative energy sources (Toyama City, 2017b). To revitalize public transportation, Toyama City terminated and converted JR Toyamako Line to established the light rail transit (LRT), a street-level tram line, "building a convenient public transport network and making the tram a transport friendly mode for all population segments as the basic development policy" (Muro, 2009, p. 25). LRTs are run through public-private partnerships where the city provides public funds for their renovation/construction and private companies fund and operate the service (Toyama City, 2017a). LRT has north and south lines that connect the ocean front and the city center. This line is 
called Portram. A city loop line that allows passengers to go around the city is called Centram. These LRTs are also connected to the Shinkansen (bullet train) line and other local tram lines, creating an extensive network for public transportation. These rail lines make it convenient for citizens to commute and travel within and outside the city. The number of passengers of LRT, as compared to those of the former JR Toyamako Line, has increased by 2.6 times since 2009: 2.1 times more passengers travel on weekdays and 3.4 times more passengers travel on weekends since its establishment. It may be noteworthy that one fourth of these passengers changed their commuting means from private cars to LRTs (Toyama City, 2017a). According to the personnel at the Environmental Policy Section at Toyama City Hall, "LRT is not a simple mobility but promotional story to enliven the region. Introducing LRT itself would not mean much without a localized story. We emphasized branding Toyama City as a whole with integration on LRT. We surveyed citizens and added their opinions to the story" (Mitsuharu Tohfuku, personal communication, 2018/09/13). To further help citizens move around flexibly, Toyama City also established a ride-share bicycle system: numerous stations have been placed around the city center for this eco-friendly bicycle system (Japan for Sustainability, 2010). This shift is estimated to contribute to the reduction of 436 tons of CO2 (Muro, 2009).

To concentrate city functions in the city center and along the transportation lines toward establishing a compact city, Toyama City encourages both residents and businesses to relocate to zones along public transport lines (Toyama City, 2017a). The city has set residence encouragement zones around public transportation line zones (with a surface area of 3,387 hectares, rail and tram line zones being defined as a 500 meter buffer radius around rail and tram line stations, and bus stop zones being a 300 meter buffer radius around bus stops) and offers financial incentives (equivalent to 5,000 USD for purchasing houses or 100 USD for renting apartments) to residents willing to move within 500 meters of the public transportation zone (Mitsuharu Tohfuku, personal communication, 2018/09/13). In 2016, $57 \%$ of the city population was living in the residence encouragement zones, a 9\% increase over 2005 (Toyama City, 2017a).

Another area of the city's focus to help establish a compact city is sustainable renewable energy and efficient energy use. With Toyama Prefecture enjoying the second most affluent water resources, with a number of rapid stream rivers, the city plans increase the number of its micro-hydroelectric power plants from 23 as of 2012, to at least 45 by 2021 and for the solar energy capacity to be more than tripled during that same time frame (Japan Times, 2017/7/23). Toyama City subsidizes home construction companies that produce eco-friendly houses with energy saving systems and/or solar power generation facilities. The city also subsidizes citizens who purchase these eco-houses in the city center. The ratio of residents living in its center-28\% in 2005-is expected to rise to about $42 \%$ by 2025 . The city has also built micro hydroelectric power generation facilities on agricultural canals (Toyama City, 2017b). In addition, Toyama City has made an Eco Town Plan to help build a sustainable society by recycling energy and wastes (e.g., garbage and plastics) (Toyama City, 2014).

Owing to the city's substantial efforts working toward addressing environmental and socio-economic issues, Toyama City has been successful in promoting its eco-policies through compact city strategies nationally and internationally. Toyama City was designated as an environmental model city (EMC) in 2008 and an environmental future city (EFC) in 2011 by the Japanese government. In 2012, it was selected as an assessment case study for OECD's compact city policies, where it was profiled along with four other cities around the world (i.e., Melbourne, Vancouver, Paris, and Portland). According to personnel of Toyama City Hall, the mayor of Toyama City mentioned their success of EMC and EFC in various national and international events, which interested OECD (Mitsuharu Tohfuku, personal communication, 2018/09/13). In 2014, it was selected as a model city for the United Nations Sustainable Energy for All (SE4ALL) initiative and also selected for Rockefeller's 100 resilient cities program (100 RC). In 2016, the city also signed an individual MOU Partnership with the World Bank for its city partnership program that intends to enhance compact city design, waste management, flood control, and the challenges of a rapidly aging population (Toyama City, 2017b; World Bank, 2016).

This article discusses Toyama City's strategies in each of the above-stated initiatives focusing on EMC, EFC, SE4ALL, and 100 RC. OECD's and World Bank's cases are not discussed in this article because, while they were invaluable, the former is an assessment and the latter is a partnership, rather than a set of practices meant to achieve eco-policy and compact city goals. Some strategies overlap across initiatives, but they will be reiterated to examine which strategies play pivotal roles in promoting the city's eco-policies because these repeated strategies are arguably important. This study may provide other eco-cities with some insights to promote their eco-policies: Toyama's case can provide good practices and sound expertise of other cities around the world that have faced similar problems and share what is has learned. To begin with, the next section explains EMCs followed by Toyama's activities as an EMC. 


\section{Method}

This study mainly employs literature reviews. Given that there have been few pieces of academic literature on Toyama City's eco-policies, this study did not use systematic literature review but critical/narrative literature review. To complement the literature reviews, interviews with personnel from the Environmental Policy Section at the Toyama City Hall are used. The interviews took place at the Toyama City Hall on September 13, 2018. Before the interviews, the author explained the personnel about the objectives of the research. Verbal consent was given by the personnel. The interview lasted approximately one hour. The collected data were analyzed and integrated into the description of the literature review.

\section{Toyama City's Activities as an Environmental Model City (EMC)}

Between 2008 and 2009, thirteen cities (Obihiro, Shimokawa, Yokohama, Toyama, Kitakyushu, Minamata, Chiyoda, Iida, Toyota, Kyoto, Sakai, Yusuhara, and Miyakojima) were selected as EMCs by the Japanese government. The EMC initiative was designed to establish a low-carbon society through the reduction of greenhouse gas emissions and to set an example of eco-cities for the rest of the world. These EMCs were selected mainly based on the following conditions: cities aiming at reducing substantial amount of $\mathrm{CO} 2$ emissions and developing pioneering and exemplary eco-projects that are feasibly adaptable and sustainable in local contexts (Kita, 2010). All EMCs have common features: to redevelop themselves as a compact city (a community where citizens can walk without necessity of private transportation such as personal vehicles), to improve transportation infrastructure (e.g., public transportation facilities such as light passenger cars and electric cars), and to change residential style (e.g., energy-saving or smart houses) (Cabinet of Japan, 2015).

In response to environmental and socioeconomic issues influenced by the 2011 Great East Japan Earthquake in the northern part of Japan, including that of aging, as the younger population tends to move outside the affected areas after the earthquake, 10 more cities (Tsukuba, Niigata, Mitake, Kobe, Amagasaki, Nishiawakurason, Matsuyama, Niseko, Ikoma, and Oguni) were added as EMCs to address these issues (Japan for Sustainability, 2014).

As already mentioned, Toyama City had been working on realizing a compact city before the EMC designation, notably the establishment of LRT in the mid 2000s. The objective of the EMC initiative that pursues a low carbon society suited these city's efforts. Toyama City's action plan for this initiative is entitled "the $\mathrm{CO} 2$ Reduction Plan by Compact City Strategy." It may be important to note that Toyama's compact city strategy is not exclusive to its EMC status but is essential to promote its eco-policies in all national and international eco-initiatives in which the city is involved. As personnel from the Environmental Policy Section at Toyama City Hall affirms, the city's compact city strategy has been consistent throughout its national and international eco-initiatives (Mitsuharu Tohfuku, personal communication, 2018/09/13). This compact city strategy is composed of four different elements as shown below (Kita, 2010; Toyama City, 2008).

\subsection{Strategy 1: Creation of a Compact City Focused Around Public Transportation}

Toyama City aims to create a seamless mobility environment, to produce efficient energy systems in the city center by concentrating commerce, medical, and welfare functions along the transportation lines and to improve energy efficiency in residences and concentrate them along the transportation lines in the city center. To do so, In line with the compact city strategy, Toyama City has established the LRT—Shinaknsen (Bullet train)—Bus Network and rebuilt the transportation infrastructure around the Toyama Station. The city also intends to change citizens' habits regarding transportation by introducing the aforesaid bicycle ride-share program, encouraging residence in the city center, and revitalizing the city center through urban development projects (Toyama City, 2015).

\subsection{Strategy 2: Effective Use of Energy}

Toyama City has introduced renewable energy systems, such as solar-power generation and high-energy efficiency equipment, into residential houses (e.g., the home energy management system: HEMS) and offices (e.g., the building energy management system: BEMS). The city has also been establishing new charging stations for new generation cars (NGCs) such as electric vehicles and plug-in hybrid vehicles, and making the aforesaid Eco-Town Plan for energy efficient waste management (Toyama City, 2015).

\subsection{Strategy 3: Raising Energy Efficiency Awareness}

Toyama City aims to create opportunities and venues for citizens to learn about the environment and energy efficiency. The city places a particular emphasis on environmental education to help raise environmental awareness in younger generations. Toyoma City provides opportunities to experience and learn about micro hydropower generation systems, solar panel arrays, and wood biomass fuel generation facilities. For instance, 
Toyama's Energy Park of the Next Generation has been built as a showcase for sustainable energy facilities (Ministry of Economy, Trade, and Industry, 2016). Hence, the city has been raising citizens' awareness of an eco-friendly and energy efficient lifestyle, supporting energy saving activities by setting targets (e.g., "no private car days"), and promoting waste reduction and recycling (e.g., food waste and plastic) (Toyama City, 2015).

\subsection{Strategy 4: Promotion of International Energy Efficiency in Developing Countries}

Toyama City has been presenting its eco-strategies at various national and international events and introducing renewable energy technologies to cities in developing nations such as Bali (Indonesia) and Iskandar (Malaysia) with the support of the Japan International Cooperation Agency (known as JICA, a governmental organization for developmental assistance). For example, the micro-hydropower generation system has been implemented by Toyama-based companies in Bali. These companies are currently working on a similar project in Iskandar as well. These efforts are expected to have positive effects on sustainable socio-economic development, the very purpose of promoting eco-policies such as realization of a society without relying on cars, the creation of regional vitality, administrative cost reduction on urban management, and promotion of the city's eco-policy nationally and internationally (Toyama City, 2015).

\section{Toyama City's Activities as an Environmental Future City (EFC)}

The concept of EFCs was created in the Future City Initiative (FCI), which was launched by the Japanese government in 2011 in response to the issues of declining and aging population as well as the environment. Eleven cities (Higashimatsushima, Iwanuma, Kamaishi, Kashiwa, Kesen, Kitakyusyu, Minamisouma, Shimokawa, Shinchi, Toyama, and Yokohama) have been authorized as EFCs through the initiative. Kitakyusyu, Shimokawa, Toyama, and Yokohama are also EMCs (the rest, except Kashiwa, are cities affected by the 2011 Great East Japan Earthquake. Aging population is a serious concern in these affected areas, as many young citizens left these affected areas due to the earthquake and the subsequent tsunami and radiation from the nuclear power plant destroyed by the tsunami). In 2050, it is estimated that citizens aged 65 and older will account for $40 \%$ of the Japanese population. It is therefore a matter of urgency to establish cities where the elderly are able to live healthily and peacefully (Japan for Sustainability, 2014).

To do so, it is essential for relevant stakeholders to consider environmental, social, and economic values. Environmental values includes low carbon, water, atmosphere, biodiversity, and waste management. Economic value includes tourism, industry, business, and partnerships of the public and private sectors. Social values are related to medical services, social welfare, disaster prevention, and education. EFCs are model cities that encourage and strive to uphold these values. In the near future, many countries are expected to face aging and environmental issues. Japan's experience with addressing these problems might suggest meaningful lessons for places with aging populations (Japan for Sustainability, 2014).

In 2011, Toyama was designated as an EFC with the slogan "a city aiming for creation of human-centered new value for responding to the environment and super aging" (Toyama City, 2017). According to the personnel from the Environmental Policy Section at Toyama City Hall, "FCI was an opportunity for us to address the regional issue of aging, health, and safety for the elderly. ECI was enacted when we were seeking other aspects than environmental ones. We made a model change in the timing of beciming an EFC" (Mitsuharu Tohfuku, personal communication, 2018/09/13). Below are fifteen action plans made by Toyama City for the FCI. These actions include goals targeting energy efficiency (including sustainable energy), urban planning, public transportation, the compact city revitalization of the city center, agriculture and forests, residence, commerce and industry, and social welfare (Toyama City, 2017).

\section{Toyama City’s EFC plans 2017-2022}

1. Formation of LRT network

2. Organization of transportation nodes

3. Enhanced service level of bus transportation as a public transportation axis

4. Organization of safe and environmentally smart model district

5. Revitalizing agriculture utilizing renewable energy-Visualization of renewable energy utilizing farming support center

6. Construction of medicinal plant cultivation factory

7. Formation of health and socialization town

8. Creation of community-based socialization space by local community 
9. Promotion of diversified business for the industrialization of perillas

10. Eco-forest Toyama (forestry's consolidation of operations)

11. Establishment of a museum called Symbiosis of humans and nature and renewable energy in Kurehakyuryo

12. Creation of community business models in rural areas

13. Construction of a sustainable social system by promoting the use of hydrogen energy

14. Effective use of consumed gas in sewage treatment facilities

15. Promotion of inter-city cooperation by packaging the future city initiative of Toyama

The principal strategies of Toyama City to achieve its EFC status are similar to those guiding its EMC initiatives. They center around public transportation (Actions 1 through 4), as it plays a crucial role in addressing issues related to both environmental sustainability and aging. Action 4, for example, intends to organize a safe and environmentally smart model district: In a low or unused area along public transportation, the city will develop a model district that is environmentally friendly, safe, and comfortable and promote high quality of life with convenience (Toyama City, 2014).

It is also notable that, along with public transportation, as is the case with EMC actions, EFC focuses on addressing energy issues (Actions 5, 11, 13, and 14). Action 5, for example, intends to revitalize agriculture utilizing renewable energy: Toyama City implements a project called "Visualization of renewable energy utilizing farming support center" to encourage the revitalization of the agricultural sector using renewable energy as intended in the EFC plan. It is hoped that farmers who visit the center to experience the effectiveness of renewable energy will implement and use it for their agricultural activities to reduce carbon emissions in farming areas. Relevantly, industrialization of perilas plays a key role in the city's FCI. According to the personnel from the Environmental Policy Section at Toyama City Hall, "perilla oil had traditionally been used as energy for lamps, but has not been used in recent years. The city government started enlivening it by incorporating with 90 organizations and industrializing it as food for meals at school and hospitals where the local elderly work" (Mitsuharu Tohfuku, personal communication, 2018/09/13).

Finally, the city has expanded its international cooperation projects. In addition to the aforesaid projects in Bali, Indonesia and Iskandar, Malaysia, Toyama City has been promoting an international development project to improve the garbage recycling system in Mogi das Cruzes, Brazil (Toyama City, 2014).

\section{Toyama City's Activities as a Model City for the United Nations Sustainable Energy for All (SE4ALL)}

In September 2014, thirteen international cities (Almaty, Kazakhstan; Astana, Kazakhstan; Cetinje, Montenegro; Jina, China; Leo, Mexico; Lima, Peru; Manila, the Philippines; Rio de Janeiro, Brazil; Thimphu, Bhutan; Toyama, Japan; Ulan Bator, Mongol; Warszawa, Poland; Iskandar, Puteri) were selected by the UN SE4ALL initiative as model cities with the goal of improving sustainable energy efficiency. SE4ALL aims to achieve a clean, fair and prosperous world for all, realizing universal access to sustainable energy by leaders transferring partnerships to brokers and opening up finances (United Nations, 2014). To do so, the SE4ALL connects stakeholders, organizes evidence, benchmarks progress, amplifies partner voices, and shares stories of success. In launching the initiative, the then UN Secretary General Ban Ki-moon stated that energy is fundamental to advance for all countries, and "energy is the golden thread that connects economic growth, increased social equity, and an environment that allows the world to thrive" (United Nations, 2014).

However, more than one billion people worldwide have no access to electricity and nearly three billion people have no access to clean fuels for cooking (Rogelj et al., 2013). Reflecting these needs, SE4ALL is working toward three goals to be achieved by 2030 :

- Ensuring universal access to modern energy services

- Doubling the share of renewable energy in the global energy mix

- Doubling the global rate of improvement in energy efficiency

Ensuring universal access means providing electricity to remote and poor rural areas, replacing traditional biomass (Rogelj et al., 2013). Doubling the share of renewable energy requires increasing the share of renewables used to create final energy (the energy available to actual users) from $15 \%$ to $30 \%$ by 2030 . Energy efficiency here means an average improvement rate for global energy intensity (measured here in units of final energy per global gross domestic product) (Rogelj et al., 2013). Doubling this means that global energy intensity improves by an average rate of $2.4 \%$ per year between 2010 and 2030 (compared with the historical rate of $1.2 \%$ per year) (Rogelj et al., 2013). These goals are also shown in the sustainable development goal (SDG) 7 that seeks 
"affordable, reliable, sustainable and modern energy for all people" (UN Chronicle, 2015). Securing sustainable energy access is important not only for SDG 7 but also for achieving all SDGs. Without sustainable energy, it is impossible to develop while protecting people and the earth simultaneously.

Member cities selected for this initiative are provided with strategic guidance by the Advisory Committee of SE4ALL, an institution co-chaired by the UN Secretary-General and the President of the World Bank, and they are served by over 40 ministerial or highest level leaders selected from governments, international organizations, and civil society. More than 100 countries work with SE4ALL to provide financial contributions and formulate national strategies to achieve the SE4ALL's goals (Sustainable Energy for All, 2016).

Toyama City was selected as a model city by SE4ALL in large part because of its efforts and work illustrated in the EMC and EFC initiatives and for its future prospects of continuing to promote sustainable energy and improve energy efficiency (Japan for Sustainability, 2014). Being selected for a member city of SE4ALL is a notable accomplishment for Toyama City as an EMC and EFC because one of the main objectives of these initiatives is to propagate these Japanese initiatives and for these cities to be recognized internationally. Toyama City's activities for SE4ALL are mostly in line with the EMC and EFC initiatives based on the compact city strategy. Connected to SE4ALL, Toyama City has set the goal of doubling the pace of energy efficiency improvement in the city by 2030 through: 1) Building an effective municipal structure network; 2) Collaborating with industry, universities, and citizens; and 3) Establishing strong networks with other cities and countries.

As for building an effective municipal structure network, Toyama City encourages collaboration among all city departments concerned with energy, urban planning, transportation, agriculture and forests, commerce and industry, welfare, culture, and education (Toyama City, 2017). Regarding collaboration with industry, universities, and citizens, Toyama City develops networks among the city's academic institutions, such as the University of Toyama, and local companies in order to maximize the knowledge resources available to local industries, government, and the academy.

Concerning the establishment of strong networks with other cities and countries, as already mentioned, Toyama City collaborates with international institutions and networks like UN, OECD, World Bank, and the Rockefeller Foundation. Toyama City also supports the energy efficiency measures of developing countries, primarily in Southeast Asia, to promote city-to-city collaboration on sustainable, decarbonized development activities (Toyama City, 2015).

\section{Toyama City's Activities as One of Rockefeller's 100 Resilient Cities}

$100 \mathrm{RC}$ was created in 2014 by the Rockefeller Foundation to enhance a global practice of resilience among governments, NGOs, the private sector, and citizens. A resilient city is defined as "a city capable to withstand or absorb the impact of shocks and stresses through adaptation or transformation, in order to guarantee long-term sustainability, as well as its basic functions, characteristics and structures" (Papa et al, 2015, p. 22). A shock here means a sudden, acute event that occurs infrequently, such as a major flood, earthquake or disease pandemic. A stress refers to a chronic condition that gradually weakens the city's fabric on a daily or cyclical basis, such as high rates of unemployment, severe traffic congestion or social inequalities (Papa et al., 2015).

According to Newman et al. (2009), resilient cities adapt to change by creating systems that withstand change, such as diversity of transportation and land-use systems and multiple sources of renewable power that allows a city to survive shortages in fuel supplies. $100 \mathrm{RC}$ helps cities around the world become more resilient to the physical, social, and economic challenges including the above stated shocks and stresses. To address these issues, a city needs to respond to adverse events and to deliver basic functions to all populations. The $100 \mathrm{RC}$ cities are provided with the resources to gain resilience along the following four main pathways:

1. Financial and logistical guidance for establishing an innovative position in city government, called a Chief Resilience Officer, who will lead the city's resilience efforts

2. Expert support for development of a Resilience Strategy

3. Access to solutions, service providers, and partners from the private, public and NGO sectors who can help develop and implement their Resilience Strategies

4. A global network of member cities who can learn from and help each other (100 Resilient Cities, 2018c)

In conjunction with 100RC, Toyama City elaborated on the Toyama Resilience Strategy to foster an entrepreneurial and flexible economy and nurture citizens' lives by improving quality of life, reducing risk, and expanding sustainable networks. Toyama City's strategy was developed based on the aforesaid comprehensive compact city plans and also the new Toyama Vision 2050 or Resilient Toyama. According to the personnel from 
the Environmental Policy Section at Toyama City Hall, "We interpreted RC as a sustainable city...after all, a RC and a sustainable city are a compact city" (Mitsuharu Tohfuku, personal communication, 2018/09/13). The new Toyama vision is for the city to become a place of innovation and environment-friendly living, where strong community bonds help citizens become resilient. Resilient Toyama has four integral elements, which create a logical structure for the city's comprehensive Resilience Strategy: people, infrastructure, socio-economic prosperity, and environment (100 Resilient Cities, 2017).

Among them, the city values people the most. The city engages hundreds of stakeholders through a wide range of consultation meetings with citizens, the private sector, community groups, research institutions, international organizations, and NGOs. Dr. Joseph Runzo-Inada, Toyama's Chief Resilience Officer, notes, "while Toyama is internationally recognized as a leading model for city resilience, the underlying lesson of our resilience strategy is that Toyama's success is fundamentally not about precise policies, priorities or programs; it is about nurturing the resilient spirit of its citizens. There will be no future success without the enduring resilient spirit of Toyama's citizens" (100 Resilient Cities, 2017).

Resilient Toyama focuses on several interconnected areas for action, each with its own goals, initiatives and projects to strengthen the city and its communities in order to address its key challenges including an aging and declining population, efficient transportation systems, natural disasters like flooding, and waste management.

Toyama's resilience elements, initiatives, and sub-initiatives are summarized below:

1. Comprehensive smart city initiative to improve city services and operations in real time, allowing flexibility and integration with stakeholders by creating a 30 year smart city plan, building an integrated lifeline platform, and creating and promoting the use of an open data platform.

2. Public transportation to improve accessibility across Toyama, promoting inclusivity, mobility and integration of communities, businesses and public services by completing north-south tram line connections under Toyama Station to increase the number of LRT passengers, promoting the city center and other well connected zones as residential and commercial areas to increase use of public transport and decrease car use, and modernizing old and building new train stations in congested and underserved areas.

3. Water/waste/energy management to provide robust, integrated and clean solutions to Toyama's energy, water and waste management by revising comprehensive environment plans and developing the city's waste-to-energy industry.

4. Disaster preparation and response to improve the robustness of our critical infrastructure and ensure the resourcefulness of our people to respond effectively in emergencies by embedding resilience as a principle of infrastructure design and maintenance, improving access to community infrastructure, and improving flood control.

5. Integration of city center to seacoast area to increase business activity and visitor numbers in the downtown and seacoast area, while preserving the character of the city and preserving the seacoast area by developing a master plan for revitalization of the city center to seacoast corridor, attracting new business activities to locate in the city center to seacoast area, and creating community disaster management teams.

6. Rural Toyama and agricultural sustainability to protect and enhance the rural areas which are vital for our regional economy, our identity, and environmental quality by conserving the city's landscape and forests and promoting high-value agricultural products.

7. Business investment to diversify Toyama's economy and support long-term prosperity for Toyama's citizens, while attracting new working-age residents that can contribute to the city's financial stability by developing a comprehensive 30 year business investment plan, promoting second home ownership, and establishing an incubator program for start-ups.

8. Tourism to diversify our economic base and celebrate Toyama's unique identity, attracting tourists and fostering a sense of civic pride by developing Toyama's digital services, promoting Toyama as a tourist destination, and creating an international identity for Toyama (i.e., enhancing recognition of Toyama's identity domestically and internationally through branding campaigns).

9. Citizen health, wellbeing, and participation to ensure a good quality of life and self-realization for citizens of all ages, by enabling active participation in inclusive communities by upgrading community centers, implementing intergenerational programs for community participation, facilitating employment opportunities for elderly and disabled people, introducing initiatives to ensure working parents can continue to participate in the workplace, promoting cultural events, and encouraging an active lifestyle for the older 
generation.

10. Conservation and environmental education to preserve nature for future generations and conserve nature and accessibility to nature for citizen's self-realization and resilience by hosting an international summit on the marine environment, promoting 3R (reduce, reuse, recycle) projects, and increasing environmental education at ECO Town-where waste is turned into usable products.

(Toyama City, 2017b)

\section{Discussion and Conclusion}

As seen so far, Toyama City has been successful in promoting eco-policies and is recognized as a leading model for eco-cities by the Japanese national government and international organizations such as the United Nations and the Rockefeller Foundation as well as OECD and the World Bank. The process of how it became recognized as a model city nationally and internationally is noteworthy. Toyama City first became an EMC because of the city's work and efforts toward addressing environmental and socioeconomic issues based on its compact city strategy by revitalizing public transportation, concentrating city functions in the city center and along transportation lines, and promoting energy efficiency and alternative energy sources. Toyama's compact city strategy fit the EMC initiative that pursued the low carbon society and the city promoted the CO2 Reduction Plan through the compact city strategy by focusing on public transportation, effective use of energy, raising energy efficiency awareness, and promoting international energy efficiency in developing countries. Toyama's compact city strategy also matched with the objectives of the subsequent FCI initiative (i.e., addressing the issues of environmental and socioeconomic issues, especially related to the aging population). Four EFCs are also EMCs, but Toyama City is the only Japanese city that has been selected by UNSE4ALL and 100 RC. How has the city been selected as a model city by these organizations while other cities have failed to do so? The simplest answer may be the city's strategies to gain competitive advantage.

Given limited resources available to support eco-city initiatives by these organizations, consciously or unconsciously, Toyama City has competed against other cities and won because it has (created) competitive advantage, competing strength gained over others by offering greater values (Ehmke, 2012). According to Porter (1985; 1996), competitive advantage can be generated through the following factors: 1) cost leadership; 2) differentiation; and 3) focus. Cost leadership is an advantage in that an organization offers the same services as its competitors but at a lower cost. Differentiation is an advantage where an organization delivers higher quality services for the same price as its competitors. Focus is a strategy in which an organization concentrates on narrow, exclusive segments and establishes market niches. An organization can possess competitive advantage when it creates and/or adds unique value (Campbell et al., 2012; Gaddis Ross, 2014; Goldsmith, 2013). Among the above-stated factors, Toyama City's success may be attributed to differentiation and focus.

While the city's strategy is comprehensive, its focus on public transportation, evolved around LRT, makes the city unique and differentiates its eco-policies from those of other cities. Back in the 2000s, the use of LRT was considered out of date and obsolete in Japan. Nonetheless, the city decided to establish the LRT system and used it as a pivotal tool for success. That is innovation. Although innovation is often considered new technological invention, using old things and ideas in new ways is also innovation (Hargadon \& Sutton, 2000; Sanger \& Levin, 1992). Since innovation is unique and valuable (Fetterhoff \& Voelkel, 2006; Kim \& Mauborgne, 1997; Prahalad \& Ramaswamy, 2004), it entails competitive advantage. What can other cities with intentions to promote eco-policies learn from Toyama's case? As is Toyama City, most cities have limited financial, human, and technological resources. Toyama's case suggests that cities should focus on investing their resources into one or a few segments that are crucial in promoting their eco-policies, such as transportation and energy. In the case of Toyama City's eco-policy, that was public transportation, notably LRT, and to a lesser extent, sustainable energy, agriculture, business, and so forth. If one specific segment becomes a competitive advantage, unique with great value, it can attract additional resources for other segments such as business and agriculture, as illustrated by Toyama City.

\section{Acknowledgments}

I would like to thank Mr. Mitsuharu Tofuku from Toyama City Hall for supporting me with research. I also would like to thank Ezra Anton Greene for editing this paper.

\section{References}

Cabinet of Japan. (2015). Overview of environmental model cities. Retrieved from https://www.kantei.go.jp/jp/singi/tiiki/kankyo

Campbell, B. A., Coff, R., \& Kryscynski, D. (2012). Rethinking sustained competitive advantage from human 
capital. Academy of Management Review, 37(3), 315-318.

Ehmke, C. (2012). Strategies for competitive advantage. Retrieved from Ag.arizona.edu/arec/wemc/nichemarkets/05compatitiveadvantage.pdf.

Fetterhoff, T. J., \& Voelkel, D. (2006). Managing open innovation in biotechnology. Research-Technology Management, 49(3), 14-18.

Future City Initiative. (2017). Concept of "Future City" Initiative. Retrieved from https://www.env.go.jp/policy/hakusyo/zu/h25/pdf/1-2.pdf

Gaddis Ross, D. (2014). Taking a chance: A formal model of how firms use risk in strategic interaction with other firms. Academy of Management Review, 39(2), 202-226.

Goldsmith, G. (2013). Rethinking the company's competitive advantage. Financial Executive, 29, 14-17.

Hargadon, A., \& Sutton, R. I. (2000). Building an innovation factory. Harvard Business Review, 78(3), 157-166.

Japan for Sustainability. (2010). Japan's first bike-sharing service ready to roll in Toyama City. Retrieved from https://www.japanfs.org/en/news/archives/news_id029710.html.

Japan for Sustainability. (2014). "FutureCity" Initiative. Retrieved from https://www.japanfs.org/en/projects/future_city/index.html.

Japan Times. (2017). Toyama embarks on compact redesign to foil natural disasters, depopulation at same time. Retrieved from https://www.japantimes.co.jp/news/2017/07/23/national/toyama-embarks-compact-redesign-foil-natural-dis asters-depopulation-time/\#.Wkw4JEvLhsd

Karato, K. (2013). Toyama-shi no koukyoukoutsuseisaku to konpakuto shiti. Public Transportation Policy and Compact City in Toyama. Japan Real Estate, 26(4), 77-82.

Kim, W. C., \& Mauborgne, R. (1997). Value innovation: the Strategic logic of high growth. Harvard Business Review, 75(1), 102-112.

Kita, M. (2010). Kankyou moderutoshi no torikumi to tenkai (The eco-model city initiatives and their development). Japan Real Estate, 24(1), 34-38.

Ministry of Economy, Trade, and Industry. (2016). Energy Parks of the Next Generation. Retrieved from http://www.enecho.meti.go.jp/category/saving_and_new/saiene/park/enepa2016.pdf\#page=41.

Ministry of International Affairs and Communication. (2017). National Consensus. Retrieved from http://www.stat.go.jp/data/kokusei/2015/index.htm.

Muro, T. (2009). Compact city development using public transport. Japan Railway \& Transport Review, 52, 24-31.

Newman, P., Beatley, T., \& Boyer, H. (2009). Resilient cities: Responding to peak oil and climate change. Washington DC: Island Press.

100 Resilient Cities. (2017). Resilient Toyama: Toyama vision. Retrieved from https://www.100resilientcities.org/wp-content/uploads/2017/07/Toyama_Resilience_Strategy__PDF.pdf.

100 Resilient Cities. (2018a). Toyama's resilient challenge. Retrieved from http://www.100resilientcities.org/cities/toyama.

100 Resilient Cities. (2018b). Toyama unveils comprehensive urban resilience strategy. Retrieved from $\mathrm{http}: / / w w w .100$ resilientcities.org/toyama-unveils-comprehensive-urban-resilience-strategy.

100 Resilient Cities. (2018c). About us. Retrieved from http://www.100resilientcities.org/about-us.

Papa, R., Galderisi, A., Vigo Majello, M. C., \& Saretta, E. (2015). Smart and resilient cities. A systemic approach for developing cross-sectoral strategies in the face of climate change. Tema: Journal of Land Use, Mobility and Environment, 8(1), 19-49.

Porter, M. (1985). Competitive advantage. New York: Free Press.

Porter, M. (1996). What is strategy? Harvard Business Review, November-December, 61-78.

Prahalad, C. K., \& Ramaswamy, V. (2004). Co-creating unique value with customers. Strategy \& Leadership, 32(3), 4-9.

Rogelj, J., McCollum, D. L., \& Riahi, K. (2013). The UN's sustainable energy for all initiative is compatible 
with a warming limit of $2^{\circ} \mathrm{C}$. Nature Climate Change, 24 February 2013.

Sanger, M. B., \& Levin, M. A. (1992). Using old stuff in new ways: Innovation as a case of evolutionary tinkering. Journal of Policy Analysis and Management, 11(1), 88-115.

Sustainable Energy for All. (2016). The organization. Retrieved from https://www.seforall.org/our-mission

Toyama City. (2008). The CO2 reduction plan by the Toyama Compact City Strategy. Retrieved from http://www.kantei.go.jp/jp/singi/tiiki/kankyo/seminar2008/12toyama.english.pdf.

Toyama City. (2015). Improving energy efficiency. Retrieved from http://www.city.toyama.toyama.jp/data/open/cnt/3/13357/1/gaiyou.eng.pdf.

Toyama City. (2017a). Resilient Toyama: Toyama Vision 2050. Retrieved from https://www.100resilientcities.org/wp-content/uploads/2017/07/Toyama_Resilience_Strategy__PDF.pdf

Toyama City. (2017b). The second Toyama City's action plans toward a future model city. Retrieved from http://www.city.toyama.toyama.jp/data/open/cnt/3/9930/1/dai2ji_kankyoumiraitoshikeikaku_honntai.pdf

Trott, P., \& Hartmann, D. (2009). Why 'open innovation' is old wine in new bottles. International Journal of Innovation Management, 13(4), 715-736.

United Nations. (2014). Sustainable energy 'Golden Thread' connecting economic growth, increased social equity, Secretary-General tells ministerial meeting. Retrieved from https://www.un.org/press/en/2014/sgsm15839.doc.htm

UN Chronicle. (2015). Goal 7 - Ensure access to affordable, reliable, sustainable and modern energy for all. Retrieved

from https://unchronicle.un.org/article/goal-7-ensure-access-affordable-reliable-sustainable-and-modern-energy-a 11.

World Bank. (2017). City partnership program. Retrieved from http://www.worldbank.org/en/news/feature/2017/01/12/city-partnership-program-addressing-complex-devel opment-challenges-together

\section{Copyrights}

Copyright for this article is retained by the author(s), with first publication rights granted to the journal.

This is an open-access article distributed under the terms and conditions of the Creative Commons Attribution license (http://creativecommons.org/licenses/by/4.0/). 